\title{
The influence of the Big 5 personality traits on young people's political
} consumer behavior

Quintelier, Ellen (ellen.quintelier@soc.kuleuven.be)

Article accepted for publication in Young Consumers ${ }^{1}$

\section{Abstract}

Purpose In this article we use the "Big Five" personality structure (Openness to Experience, Conscientiousness, Extraversion, Agreeableness and Emotional Stability) to explore the relationship with political consumer behavior.

Design/methodology/approach Political consumer behavior is (not) buying products for social, political or environmental reasons. Cited motivations for political consumption include preserving the environment, developing a sustainable economy or using boycotts as political pressure, alongside social reasons such as reducing child labor. We explored this relationship among two representative studies of young people using OLS regression. Findings We concluded that in particular openness to experience leads to more political consumer behavior. Agreeableness or trust in people also often has a positive effect on political consumer behavior, while the effects of extraversion tend on the contrary to be negative.

Social implications The research can influence how marketers deal with fair trade products or how boycotts can attract larger audiences. Through this knowledge, social responsibility and environmental conscientiousness will increase.

Originality/value This article focuses on the personality traits and motivations of the political consumers and how these personality traits interact with the attitudes that motivate political consumption using representative samples of young people. It also focuses on a specific and different outcome, political consumption, whereas most studies focused solely on single items of pro-environmental behavior.

\section{Keywords:}

Political consumer behavior, personality, buycott, boycott

\footnotetext{
${ }^{1}$ Author manuscript: the content is identical to the content of the published paper, but without the final typesetting by the publisher
} 


\section{Introduction}

Political consumer behavior also referred to as ethical consumption is a free consumer choice motivated by political, social or environmental concerns which can take on two main forms: not buying certain products (boycotting) or specifically buying products with a fair trade or organic label (buycotting) (Renard, 2003, Shaw et al., 2006). The reasons often cited as motivation for these consumer choices are ecological (e.g. environmental preservation), political (e.g. boycotts as political pressure) or social (e.g. child labor concerns). Such ethical or green products play an increasingly important role in the people's purchasing behavior, although their market share in Europe remains limited (approx. 1-6\%) (Carrigan and Attalla, 2001). One exception is a $16 \%$ market share for bananas in Switzerland (Renard, 2003, De Pelsmacker et al., 2005, Bray et al., 2011). Despite the more expensive price of these ethical or green products, consumers are willing to pay more because of the quality, the status it incorporates or the values they promote (Renard, 2003, Bray et al., 2011, Zabkar and Hosta, 2013).

This article will not focus on the socio-demographic variables of consumers who choose to buy fair trade products, or avoid buying certain other products (De Pelsmacker et al., 2005, Hirsh, 2010, Bray et al., 2011). Instead, it will focus on the personality traits and motivations of these political consumers, and how these personality traits interact with attitudes that motivate political consumption suggested in earlier research (Zabkar and Hosta, 2013, Griskevicius et al., 2010). We explore this relationship in an attempt to gain a more complete understanding of why people might be interested in a more sustainable economy and lifestyle. Furthermore, there are good reasons to assume that certain personality traits make people more likely to behave as political consumers: people who are willing to try new things or sympathize with a product's underlying philosophy (such as a decent income for cacao farmers) are more likely to consume ethically (Zabkar and Hosta, 2013). We expect certain personality traits to be more susceptible to these motivations than others, and we will also 
explore how these personality traits interact with environmental and political reasons to buy ethical products (Shaw et al., 2006).

A better understanding of how personality traits affect political consumption and how these interact with other motivations to consume ethically is important for several reasons. A first reason is that environmental preservation has become very important to sustain future quality of life, as stated by many scientists, politicians and pressure groups (Young et al., 2010). Analyzing why some people's personality traits make them more likely to choose ethical products is important so that policy makers and marketers know how to sustain and increase political consumption (Markowitz et al., 2012, Shaw and Black, 2010). For instance, if marketers know that people who are open to new experiences are more likely to buy ethical products, they can develop strategies to direct these people to more ethical alternatives.

In this study, we focus on young people, because they tend to buy more ethical products (or at least to have the intention to do so) (Stolle et al., 2005, Shah et al., 2012), and once they have done so a few times, this is more likely to develop into a long-term habit. This is also how this study differs from previous studies, which mainly focused on adult or limited undergraduate populations (Milfont and Sibley, 2012, Markowitz et al., 2012, Zabkar and Hosta, 2013). Furthermore, this study focuses on a specific and different outcome, i.e. political consumption, whereas most studies only examined pro-environmental behavior such as energy conservation, recycling, litter collection (Milfont and Sibley, 2012, Markowitz et al., 2012) or ecological concerns (Hirsh, 2010). Although Markowitz et al. (2012) also investigated organic food purchases, this was included in a sum scale of pro-environmental behavior, which did not allow the effect of personality on this single item to be distinguished. Although Fray and Martinez (2006b) did explore the effects of personality using a broad scale of political consumer behavior based on people's actual commitment to engage, their sample was designed differently and they did not control for background variables. 


\section{Personality traits \& political consumption}

There are several different theories about how personality traits should be measured (McCrae and Costa, 2003, Mondak, 2010), but the most popular and widely used approach in recent years is the "Big Five" or the Five Factor Model. This theoretical framework assumes that there are five major personality traits: openness to experience, conscientiousness, extraversion, agreeableness and emotional stability. Below, we will briefly discuss the characteristics of these five personality traits and their expected relationship to political consumer behavior based on the literature.

Openness to experience is defined as "the breadth, depth, originality, and complexity of an individual's mental and experiential life" (John and Srivastava, 1999). It describes people who are not rigid in their own views, nor in their expectations toward others (Mondak, 2010). They are curious about new experiences and products, and will adopt new products more quickly than people who are less open to experience. People who are open to experience have a greater concern for the environment (Hirsh, 2010, Hirsh and Dolderman, 2007, Markowitz et al., 2012) and display more environmentally friendly behavior (Milfont and Sibley, 2012). Accordingly, we expect openness to experience to have a positive effect on political consumer behavior.

Agreeableness is described as follows: "agreeableness contrasts a prosocial and communal orientation toward others with antagonism and includes traits such as altruism, tender-mindedness, trust, and modesty" (John and Srivastava, 1999). Some of the main arguments cited in favor of fair trade are a minimum income for producers and humanitarian, environmental and equality values (Renard, 2003). Since agreeable people want to do right by others, are concerned about the environment (Hirsh, 2010, Hirsh and Dolderman, 2007), display more environmentally-friendly behavior (Milfont and Sibley, 2012) and donate more money to charity (John and Srivastava, 1999), we argue that an agreeable personality will also translate into political consumer behavior. 
Extravert persons have "an energetic approach to the social and material world and [include] traits such as sociability, activity, assertiveness, and positive emotionality" (John and Srivastava, 1999). Since extraverts are sociable people with an extensive social circle, they are more likely to come in contact with people who use fair trade products. This does not necessarily imply that they actively buy these products themselves, but on the other hand, the opportunity to talk about these issues might make them more likely to buy ethical products. In the literature no significant effects of an extravert personality on political consumer behavior or similar activities have been identified, so we have no clear hypothesis as to what the effects of this specific trait might be.

Conscientiousness is the fourth personality trait, which is described as "socially prescribed impulse control that facilitates task and goal-directed behavior, such as thinking before acting, delaying gratification, following norms and rules, and planning, organizing, and prioritizing tasks" (John and Srivastava, 1999). People who are conscientiousness are organized, punctual and reliable, which is difficult to relate to a favorable attitude towards organic, fair trade or other ethical products. However, if these people consider environmental or political commitment as their duty, then in that sense they might be more likely to consume ethical goods. Hirsh (2010), for example, found that people with a conscientiousness personality have a stronger environmental concern, while Milfont and Sibley (2012) as well as Fraj and Martinez (2006b) found that conscientiousness is linked to more environmentally conscious behavior. Therefore, we expect a positive relationship between conscientiousness and ethical purchase decisions, possibly in interaction with environmental concern or political interest (Renard, 2003).

The fifth personality trait is emotional stability. Emotionally stable people are people who do not easily feel "anxious, nervous, sad and tense" (John and Srivastava, 1999). They are calm, relaxed and reliable. We do not expect emotional stability to be a factor in political 
consumer behavior. However, it is important to include all personality traits in the analysis to obtain a more complete personality profile.

\section{Personality, motivation and political consumption}

As previous studies have already shown that pro-environmental behavior in a general sense is linked with personality, while other studies have shown that personality is also linked with specific pro-environmental attitudes (Milfont and Sibley, 2012), this study explores the effect of personality on political consumerism and on the interaction between personality (here conscientiousness) and political and environmental motivations to consume ethically. This study is in line with the view of Ajzen and Fishbein $(2005,1977)$ that attitudes precede behavior: people develop a particular attitude toward political consumption before they display specific political consumption behavior. Two attitudes will be explored in depth: environmental motivation and political motivation. People who have a more positive attitude toward the environment (Renard, 2003, Fraj and Martinez, 2006a) and are more politically interested (Neilson and Paxton, 2010, White, 2003) will be more likely to present political consumption patterns. In particular, we expect that motivations to consume ethically in combination with a conscientious personality, which makes people more likely to also act on these relevant concerns, will lead to more political consumption (Fraj and Martinez, 2006b). As a result, we expect the interaction between conscientiousness on the one hand, and political and environmental concern on the other, to have a positive effect.

\section{Method}

To test our hypotheses whether certain personality traits lead to more political consumer behavior, we used two different datasets. Political consumption was operationalized as boycotting (not buying products for political, ecological or social reasons) and/or buycotting (specifically buying products for political, ecological or social reasons). The two datasets each contain a specific population of young adolescents and young adults, and they both measure 
the five personality traits in a different way. To date, there is no clear convention on how the five personality traits are best measured, especially if one is unable or prefers not to use the full 44-item or 60-item battery. Matthews, Deary and Whiteman (2009) indicate that it is the researcher's responsibility to determine which dimensions of personality matter, and they should explicitly compare and modify their instruments accordingly. This article will therefore use different measurements for the Big Five personality traits. Additionally, we will distinguish between boycotting and buycotting and use political consumer behavior as an umbrella concept. Both activities can be considered as ethical: boycotting is "questioning the ethical credibility of companies" and buycotting is "searching for ethical alternatives". However, previous research has shown that there is an "Ethical Purchasing Gap": while around $30 \%$ of people intend to consume ethically, only $3 \%$ actually do so in practice. The questionnaires will therefore explore the effects of personality traits on both the intent to boycott/buycott and actual behavior (Bray et al., 2011). We focus on young people because their participation behavior is still evolving and therefore still has potential to change, while their personalities are largely fixed (McCrae and Costa, 2003, Roberts et al., 2006, Nicholls and Lee, 2006).

\section{Study 1}

\section{Descriptives}

The first study involves data from 3,025 21-year-olds, collected in the spring of 2011 as part of a panel study titled the Belgian Political Panel Survey (Hooghe et al., 2011). This dataset is representative both for region (64\% Dutch-speaking/Flemish; 36\% Frenchspeaking/Walloon) and gender (48\% male, 52\% female). In this dataset, personality traits were measured on the basis of 10 personality items (TIPI; Gosling et al., 2003, Rammstedt and John, 2007). The question was phrased as follows: "How well do the following statements describe your personality? I see myself as someone who..." (completely disagree, 
somewhat disagree, neither disagree nor agree, somewhat agree, totally agree $)^{2}$. Both current boycott $(M=1.38, S D=.62)$ and buycott behavior $(M=1.38, S D=.60)$ were questioned $^{3}$ (Pearson correlation: .64, $\mathrm{p}<.001)$, as well as future intent to boycott and buycott ${ }^{4}(M=1.84$, $S D=.80 ;$ Pearson correlation boycott: $.57, \mathrm{p}<.001$, with buycott: $.55, \mathrm{p}<.001)$ on a three point scale (range 1-3). Because the measures of actual behavior correlated strongly and both items gauged activities of the past year, these scores were averaged (range 1-3; $M=1.36, S D$ $=.55)$. Sex and socio-economic status were used as control variables. Socio-economic status was measured using educational track at 18 years of age (56\% general education; $24 \%$ technical education; $30 \%$ professional education $)^{5}$.

\section{Results}

First, we used one-way ANOVAs to determine whether there are significant gender and socio-economic status differences in ethical consumption. First, women were found to be more likely to buy ethical products or boycott non-ethical ones than men $(F(1,2978)=14.46$, $\left.\mathrm{p}=.000 ; M_{\text {women }}: 1.42, S D=.56 ; M_{\mathrm{men}}: 1.34, S D=.55\right)$. For the intent to boycott and buycott, we observed the same trend, with women displaying stronger intentions $(\mathrm{F}(1,2992)=22.42, \mathrm{p}$ $\left.=.000 ; M_{\text {women }}: 1.90, S D=.80 ; M_{\text {men }}: 1.77, S D=.78\right)$ to adopt this behavior than men. Second, we also checked whether the likelihood for ethical consumption is affected by socio-economic status. Again, we found significant differences for boycotting and buycotting $(\mathrm{F}(2,2876)=$ $51.57, \mathrm{p}=.000)$ and the intention for both $(\mathrm{F}(2,2890)=66.92, \mathrm{p}=.000)$. Although in the literature this has not always been a clear trend in adults, we found a higher educational track to be associated with more ethical consumption. By averaging the scores on intent to consume

\footnotetext{
2 Pearson correlations between the 2 personality items: Extraversion(2988) $=.21, \mathrm{p}<.001$, Agreeableness(2982) $=.07, \mathrm{p}<.001$, Conscientiousness(2980) $=.36, \mathrm{p}<.001$, Neuroticism(2979) $=.42, \mathrm{p}$ $<.001$ and Openness(2984) $=.25, \mathrm{p}<.001$.

${ }^{3}$ In the last year, how often have you (never, a few times, often) boycotted/buycotted certain products for political, ethical or environmental reasons.

${ }^{4}$ Do you think you will ever boycott products for political, ethical or environmental reasons? (no, maybe, yes)

${ }^{5}$ Educational track recoded for the French-speaking region
} 
ethically and the two measures of current boycotting and buycotting behavior, we found mean scores of 1.65 for former students in general education, 1.43 for students in technical education and 1.13 for students in professional education. Including these factors separately yielded a Nagelkerke $\mathrm{R}^{2}$ of 4.8 percent, indicating that there is room to explain more variance.

Table 1 presents the correlation between personality and political consumption, for which we found the results to be quite straightforward. Openness is clearly related to both forms of political consumption: the more open one is to new experiences, the more likely one will be to boycott or buycott products, and have the intention to do so. Conscientiousness, on the other hand, is related with less political consumption. As discussed above, we hypothesized that conscientious respondents will be more likely to participate in political consumption if they view this as their duty (Fraj and Martinez, 2006b), but this mechanism does not seem to apply among 21-year-olds. However, we will test this relationship more in depth in Study 2. For agreeableness, extraversion and emotional stability no significant relation to political consumption was observed.

Furthermore, we ran ordered logistic regressions to control for gender, socio-economic status and other personality traits (Table 2). Although the effect of openness on political consumption remains stable, the negative effect of conscientiousness is now slightly below significant $(\mathrm{p}=.064)$. The effects of agreeableness and emotional stability on political consumption remain insignificant. In this study, extraversion proved to be (surprisingly) negatively related to political consumption. For intent to boycott and buycott, positive effects of openness and negative effects of conscientiousness were observed. Here too, extraversion was shown to have a negative effect, whereas for agreeableness and emotional stability, again no significant effects were found. The results also showed that women are more likely to buy ethical products or boycott non-ethical ones than men, similar to the results for intent, with women showing stronger intention to boycott and boycott than men. For socio-economic 
status, we found that a higher educational track is associated with more political consumption and stronger intention.

\section{Study 2}

\section{Descriptives}

Study 2 has two main objectives: first, we will adopt a different personality scale to test the consistency of personality effects, and second, as the survey we used not only measured political but also pro-environmental attitudes, we will test how conscientiousness is affected by both political interest and environmental concern. The second dataset is a study of 3,426 Flemish 15-year olds, representative for gender (54\% male, $46 \%$ female) and educational track (44\% general education; 33\% technical education; 20\% professional education; 3\% arts education). Originally, these data were gathered to explore intergenerational transmission of social values between parents and children, i.e. the Parent-Child Socialization Study (Hooghe et al., 2012, Meeusen, forthcoming). For each personality trait, three bipolar measures were used (Mondak, 2010) ${ }^{6}$. Unfortunately, in this survey, only the intent to boycott (single item, $\mathrm{M}=1.72, \mathrm{SD}=.70)^{7}$ was measured. Again, we controlled for gender and current level of education (i.e. educational track). Political interest was measured using the following question: "How interested are you in societal issues and politics?" (not interested, a little interested, interested, very interested). Environmental concern was measured by four items, presented on a Likert scale: "I feel a sense of personal obligation to take action against toxic waste disposal in air, water, and soil"; "The government should introduce stronger measures to halt pollution since people are unable to regulate themselves"; "If asked, I would contribute money to an organization that works to improve the quality of the environment"; and "I am

\footnotetext{
${ }^{6}$ Cronbach's $\alpha$ between the 3 personality items: $\alpha$ (Extraversion) $=.76, \alpha$ (Agreeableness) $=.77$, $\alpha($ Conscientiousness $)=.66, \alpha($ Emotional Stability $)=.63$, and $\alpha($ Openness $)=.47$.

${ }^{7}$ Do you think you will boycott products in the future? (for political reasons, for environmental reasons, to protest against child labor) (never, maybe, definitely).
} 
prepared to contribute money to research on renewable energy" ( $\alpha$ : 71). We used both attitudes as direct and moderating factors.

\section{Results}

In the second study, too, we used one-way ANOVAs to determine whether there are significant gender and socio-economic status differences in ethical consumption. First, we found that girls are more likely to have the intention to boycott non-ethical products than boys $\left(\mathrm{F}(1,3376)=54.86, \mathrm{p}=.00 ; M_{\text {girls }}: 1.82, S D=.71 ; M_{\text {boys }}: 1.64, S D=.68\right)$. Second, we also checked whether socio-economic status affects the likelihood of ethical consumption. Again, we found significant differences in boycott intentions $(\mathrm{F}(3,3372)=61.61, \mathrm{p}=.00)$ for different educational tracks. The higher the educational track, the stronger the intent to consume ethically $\left(M_{\text {general }}: 1.88, S D=.70 ; M_{\text {technical }}: 1.63, S D=.67 M_{\text {arts }}: 1.78, S D=.71\right.$; $\left.M_{\text {professional: }} 1.48, S D=.65\right)$. A regression analysis of these factors yielded an explained variance of 7.5 percent $^{8}$.

In line with the first study, the sample of 15-year-olds showed a correlation between openness to experience and more political consumption (Table 1). For agreeableness, we also observed the same positive trend as in Study 1, which indicates that both personality and the intent to consume ethically are already quite clearly pronounced at a young age. For conscientiousness, extraversion and emotional stability, no significant effects were found. Secondly, we performed a regression analysis for all personality traits, gender and socioeconomic status factors, which yielded two main observations: openness has a positive effect on the intent to boycott, whereas extraversion has a negative effect, just as in Study 1. This negative effect, however, is reduced by the inclusion of political and ecological attitudes in Table 3. We observed no effect from agreeableness, conscientiousness and emotional

\footnotetext{
8 Including enviromentalism increased this explained variance to $11.2 \%$, while interest added another $6 \%$.
} 
stability. In this study, participants with a higher socio-economic status displayed stronger intention to consume politically, especially girls and younger children.

Finally, we also checked whether the interaction between conscientiousness and environmental concern or political interest leads to higher intent for political consumption (Table 3). We found that these attitudes strongly benefit the intent to boycott: more political interest results in a stronger tendency to consume ethical products. However, the interaction with conscientiousness was not found to result in higher consumption: on the contrary, more political interest and a more conscientious personality showed no effect, and we even observed negative effects for the interaction between conscientiousness and proenvironmental attitude. A possible explanation is that conscientious people are more averse to risk and reluctant to pay more money for certain products than necessary (Nga and Yien, 2013).

\section{Discussion \& conclusion}

Data obtained from two representative surveys conducted among a group of teens and adolescents show fairly consistent findings: both openness to experience and agreeableness are related to higher political consumption. These trends are clearly observable across the different samples and across different types of personality measures, also when making the distinction between the intent to consume ethically and actual behavior. These findings are in line with those presented by Hirsh (2010) for environmental concern, Milfont and Sibley (2012) for environmental values and energy conservation behavior, and Markowitz et al. (2012) for environmental practices. Furthermore, these findings expand on the study reported by Fray and Martinez (2006b). In this way, this article contributes to the understanding of the relationship between personality and behavior, in the specific context of political consumer behavior. Future studies should not only take demographic characteristics into account, but also personality traits in order to explore factors determining political consumption. Another 
aspect that should be considered is whether the motivations for political consumption (environmental concern and political interest for instance, but also other attitudes) are moderated by personality traits. This study focused on the most plausible interaction, between conscientiousness and motivational attitudes, but other combinations are possible as well.

This article explored the influence of the Big Five personality traits on political consumer behavior and found that openness to experience, in particular, leads to more political consumer behavior (Study 1,2). Creative, curious and intelligent people are more likely to buy ethical products and avoid others, which was the most consistent finding in both studies. Agreeableness, in most cases, does not lead to more ethical purchases, despite the general preconception that people who frequent fair trade markets tend to be warm, friendly, affectionate and trusting towards other people. For extraversion, the effects we observed among a representative sample of 21-year olds (Study 1) and 15-year-olds (Study 2) were clearly negative. Conscientiousness does not result in more ethical purchasing, on the contrary: decent, caring and hard-working people are less inclined to boycott and buycott (Study 1). Emotional stability was found to have no influence on political consumerism (Study 1, 2).

As the findings that openness to experience and agreeableness boost political consumption are quite consistent, producers and marketers of ethical products need to be aware of these effects. This will allow them to focus more on who the consumers of their products are, and position their products in the market as something new, a way for people to make a difference in the lives of others. It might also be effective for marketing strategies to be related to current affairs, as political consumers are generally more politically interested (Bray et al., 2011). Furthermore, focusing on environmental concerns, manufacturing and production methods, transportation, and other aspects of their products might also encourage people to buy these ethical alternatives. As a result, not only the producers, but also the 
consumer and the environment will benefit directly from the increased sales of such products. Ethical consumption can also be considered a status symbol, which is why people with a higher socio-economic status are more likely to buy these products. Marketers might therefore find it fruitful to target this group of people in particular (Zabkar and Hosta, 2013, Griskevicius et al., 2010). Nevertheless, it has to be noted that traditional factors such as gender and socio-economic status still play an important role as well, and so does political interest. The impact of political interest, however, is like the question of the chicken and the egg: does interest develop before consumption or does consumption raise interest? More recent research indicates that political consumption promotes political interest, so we have exercise caution in presenting this as the most important indicator (Quintelier and Van Deth, forthcoming).

Finally, some comments need to be made on current methods used to gauge personality. Although the "Big Five" is generally accepted as the best model to examine the main personality traits, there is no clear consensus in the literature. From a theoretical point of view, it is uncertain that personality can be measured as only five different traits, and other methods might be possible. In future research, it is therefore advisable to also consider other personality indicators. Although the results of our two studies are generally consistent, the effects are not always equally strong, and in some cases they even contradict findings of earlier studies (see, for example, Mondak, 2010). This may be due to the inconsistent use of different personality measurements, resulting in reduced content validity. Agreeableness, for example, might in one survey be presented as being social and warm, while in another survey this might be considered as having altruistic, trusting qualities. This means the same concept is measured based on different characteristics. Therefore this study, on the one hand, makes a case for the use of extensive question sets, which cover all aspects of each personality trait (as 
in the NEO-PI-R battery, for example). On the other hand, the reality in social science research is that questionnaire space is often too limited or expensive to add a 44-item battery.

Clearly, the field is in need of a reliable method to measure the five personality traits, such as the TIPI or a short version of Jeffrey Mondak's bipolar personality scales (consisting of 10 or 15 items). As this study has shown, these batteries largely produce the same results. However, from a more theoretical point of view, the basic notion of measuring personality might be problematic as well. Because personality measures are self-reported, respondents can construct their own personality, and thus construct a somewhat distorted or more extreme image of what a political consumer might be like. In order to gain a more accurate understanding of personality, and political consumption, future research should also include observer ratings of these views and behaviors.

\section{References}

Ajzen, I., Fishbein, M. 1977. Attitude-Behavior Relations: A Theoretical Analysis and Review of Empirical Research. Psychological Bulletin 84 (5): 888-918. DOI:10.1037/0033-2909.84.5.888

Ajzen, I., Fishbein, M. 2005. The Influence of Attitudes on Behavior in The handbook of attitudes, Albarracín, D., Johnson, B. T., Zanna, M. P. (ed). Erlbaum, Mahwah, 173221.

Bray, J., Johns, N., Kilburn, D. 2011. An Exploratory Study into the Factors Impeding Ethical Consumption. Journal of Business Ethics 98: 597-608. DOI 10.1007/s10551010-0640-9. 
Carrigan, M., Attalla, A. 2001. The myth of the ethical consumer - do ethics matter in purchase behavior. Journal of Consumer Marketing 18 (7): 560-577.

De Pelsmacker, P., Driesen, L., Rayp, G. 2005. Do consumers care about ethics? Willingness to pay for fair-trade coffee. Journal of Consumer Affairs 39 (2): 363-385. DOI: 10.1111/j.1745-6606.2005.00019.x.

Fraj, E., Martinez, E. 2006a. Environmental values and lifestyles as determining factors of ecological consumer behaviour: an empirical analysis. Journal of Consumer Marketing 23 (3): 133-144.

Fraj, E., Martinez, E. 2006b. Influence of personality on ecological consumer behaviour. Journal of Consumer Behaviour 5 (3): 167-181. 10.1002/cb.169.

Gosling, S. D., Rentfrow, P. J., Swann, W. B. 2003. A Very Brief Measure of the Big-Five Personality Domains. Journal of Research in Personality 37 (6): 504-528. doi.org/10.1016/S0092-6566(03)00046-1.

Griskevicius, V., Tybur, J. M., Van den Bergh, B. 2010. Going green to be seen: Status, reputation, and conspicuous conservation. Journal of Personality and Social Psychology 98 (3): 392-404. doi: 10.1037/a0017346

Hirsh, J. B. 2010. Personality and environmental concern. Journal of Environmental Psychology 30 (2): 245-248. http://dx.doi.org/10.1016/j.jenvp.2010.01.004.

Hirsh, J. B., Dolderman, D. 2007. Personality predictors of Consumerism and Environmentalism: A preliminary study. Personality and Individual Differences 43: 1583-1593. DOI: dx.doi.org/10.1016/j.paid.2007.04.015.

Hooghe, M., Havermans, N., Quintelier, E., Dassonneville, R. 2011. Belgian Political Panel Survey (BPPS) 2006-2011. Technical Report. K.U.Leuven, Leuven.

Hooghe, M., Quintelier, E., Verhaegen, S., Boonen, J., Meeusen, C. 2012. Parent-Child Socialization Study 2012. Technical Report. KU Leuven, Leuven. 
John, O. P., Srivastava, S. 1999. The Big-Five trait taxonomy: History, measurement, and theoretical perspectives in Handbook of personality: Theory and research, Pervin, L., John, O. P. (ed). Guilford, New York, 102-139.

Markowitz, E. M., Goldberg, L. R., Ashton, M. C., Lee, K. 2012. Profiling the "ProEnvironmental Individual": A Personality Perspective. Journal of Personality 80 (1): 81-111. DOI: 10.1111/j.1467-6494.2011.00721.x.

Matthews, G., Deary, I. J., Whiteman, M. C. 2009. Personality Traits. Third Edition. Cambridge University Press, Cambridge.

McCrae, R. R., Costa, P. T. J. 2003. Personality in Adulthood. A Five-Factor Theory Perspective. Guilford Press, New York.

Meeusen, C. forthcoming. The Intergenerational Transmission of Environmental Concern: The Influence of Parents and Communication Patterns within the Family. Journal of Environmental Education.

Milfont, T. L., Sibley, C. G. 2012. The Big Five personality traits and environmental engagement: Associations at the individual and societal level. Journal of Environmental Psychology 32: 187-195. http://dx.doi.org/10.1016/j.jenvp.2011.12.006.

Mondak, J. J. 2010. Personality and the Foundations of Political Behavior. Cambridge University Press, Cambridge.

Neilson, L. A., Paxton, P. 2010. Social Capital and Political Consumerism: A Multilevel Analysis. Social Problems 57 (1): 5-24. 10.1525/sp.2010.57.1.5.

Nga, J. K. H., Yien, L. K. 2013. The influence of personality trait and demographics on financial decision making among Generation Y. Young Consumers: Insight and Ideas for Responsible Marketers 14 (3): 230-243. 
Nicholls, A., Lee, N. 2006. Purchase decision-making in fair trade and the ethical purchase 'gap': ‘is there a fair trade twix?'. Journal of Strategic Marketing 14 (1): 369-386. DOI:10.1080/09652540600956384.

Quintelier, E., Van Deth, J. W. forthcoming. Supporting Democracy: Political Participation and Political Attitudes Exploring Causality Using Panel Data. Political Studies.

Rammstedt, B., John, O. P. 2007. Measuring personality in one minute or less: A 10-item short version of the Big Five Inventory in English and German. Journal of Research in Personality 41: 203-212. DOI: 10.1016/j.jrp.2006.02.001.

Renard, M.-C. 2003. Fair trade: quality, market and conventions. Journal of Rural Studies 19: 87-96. http://dx.doi.org/10.1016/S0743-0167(02)00051-7.

Roberts, B. W., Walton, K. E., Viechtbauer, W. 2006. Patterns of Mean-Level Change in Personality Traits Across the Life Course: A Meta-Analysis of Longitudinal Studies. Psychological Bulletin 132 (1): 1-25. doi: 10.1037/0033-2909.132.1.1

Shah, D. V., Friedland, L. A., Wells, C., Kim, Y. M., Rojas, H. 2012. Communication, Consumers, and Citizens: Revisiting the Politics of Consumption. The ANNALS of the American Academy of Political and Social Science 644 (1): 6-19. $10.1177 / 0002716212456349$.

Shaw, D., Black, I. 2010. Market Based Political Action: a Path to Sustainable Development? Sustainable Development 18 (6): 385-397.

Shaw, D., Newholm, T., Dickinson, R. 2006. Consumption as voting: an exploration of consumer empowerment. European Journal of Marketing 40 (9/10): 1049-1067. DOI:10.1108/03090560610681005.

Stolle, D., Hooghe, M., Micheletti, M. 2005. Politics in the Supermarket. Political Consumerism as a Form of Political Participation. International Political Science Review 26: 245-270. DOI: 10.1177/0192512105053784. 
White, C. 2003. Selling politics to young people. Young Consumers: Insight and Ideas for Responsible Marketers 4 (3): 41-46.

Young, W., Hwang, K., McDonald, S., Oates, C. J. 2010. Sustainable Consumption: Green Consumer Behaviour when Purchasing Products. Sustainable Development 18 (1): 2031. DOI: $10.1002 / \mathrm{sd} .394$.

Zabkar, V., Hosta, M. 2013. Willingness to act and environmentally conscious consumer behavior: can prosocial status perceptions help overcome the gap? International Journal of Consumer Studies 37 (3): 257-264. DOI: 10.1111/j.14706431.2012.01134.x. 
Table 1. Correlations between personality traits and ethical consumption

\begin{tabular}{|c|c|c|c|c|c|c|c|}
\hline & $\begin{array}{c}\text { Boy- and } \\
\text { buycott }\end{array}$ & $\begin{array}{l}\text { Boy- and } \\
\text { buycott } \\
\text { intention }\end{array}$ & Openness & $\begin{array}{c}\text { Conscientious } \\
\text { ness }\end{array}$ & Extraversion & Agreeableness & $\begin{array}{l}\text { Emotional } \\
\text { stability }\end{array}$ \\
\hline Boycott intention & & & $.107 * * *$ & .025 & .003 & $.056 * * *$ & .010 \\
\hline \multicolumn{8}{|c|}{ Boy- and buycott intention $.614 * * *$} \\
\hline Openness & $.255 * * *$ & $.228 * * *$ & & $.332 * * *$ & $.294 * * *$ & $.426 * * *$ & $.204 * * *$ \\
\hline Conscientiousness & $-.054 * *$ & $-.079 * * *$ & $-.036^{*}$ & & $.163 * * *$ & $.397 * * *$ & $.137 * * *$ \\
\hline Extraversion & -.006 & -.031 & $.088 * * *$ & $.167 * * *$ & & $.398 * * *$ & $.285^{* *}$ \\
\hline Agreeableness & .030 & .011 & .004 & .031 & $.036^{*}$ & & $.379 * * *$ \\
\hline Emotional stability & -.023 & -.031 & .001 & $-.057 * *$ & $.172 * * *$ & $.134 * * *$ & \\
\hline
\end{tabular}

Below the diagonal for Study 1 (BPPS), above the diagonal for Study 2 (PCSS). Sign: $\mathrm{p} \leq 0.05^{*} ; \mathrm{p} \leq 0.01$ :**; $^{*} \leq 0.001$ :***. $^{* *}$ 
Table 2. Predicting boy- and buycotting (intention) (Study 1)

\begin{tabular}{lcc}
\hline & Boy- and buycotting & $\begin{array}{c}\text { Boy- and buycotting } \\
\text { (intention) }\end{array}$ \\
\hline Openness & $.573(.045)^{* * *}$ & $.438(.041)^{* * *}$ \\
Conscientiousness & $-.093(.050) \mathrm{ns}$ & $-.156(.047)^{* * *}$ \\
Extraversion & $-.125(.056)^{*}$ & $-.142(.052)^{* *}$ \\
Agreeableness & $.087(.056) \mathrm{ns}$ & $.018(.053) \mathrm{ns}$ \\
Emotional stability & $-.028(.046) \mathrm{ns}$ & $-.033(.043) \mathrm{ns}$ \\
\hline Girl & $.211(.083)^{*}$ & $.168(.077)^{*}$ \\
Education (ref. professional education) & & \\
General education & $.903(.113)^{* * *}$ & $-1.238(.102)^{* * *}$ \\
Technical education & $.488(.096)^{* * *}$ & $-.679(.089)^{* * *}$ \\
\hline Nagelkerke R ${ }^{2}$ & .114 & .135 \\
$\mathrm{~N}$ & 3112 & 3122 \\
\hline
\end{tabular}

Source: BPPS 2011. Ordered logistic regression. Entries are coefficients (standard errors) and significances. Sign: $\mathrm{p} \leq 0.05:^{*} ; \mathrm{p} \leq 0.01:^{* *} ; \mathrm{p} \leq 0.001$ : $^{* * *}$.

Table 3. Predicting the boycott intention (Study 2)

\begin{tabular}{lccc}
\hline & $\begin{array}{c}\text { Boycott } \\
\text { intention } \\
\text { (Model 1) }\end{array}$ & $\begin{array}{c}\text { boycott } \\
\text { intention } \\
\text { (Model 2) }\end{array}$ & $\begin{array}{c}\text { Boycott } \\
\text { intention } \\
\text { (Model 3) }\end{array}$ \\
\hline Openness & $.146^{* * *}$ & $.122^{* *}$ & $.120^{* *}$ \\
Conscientiousness & .023 & -.004 & .064 \\
Extraversion & $-.079^{*}$ & -.045 & -.046 \\
Agreeableness & .030 & -.017 & -.019 \\
Emotional stability & .027 & .023 & .026 \\
Political interest & & $.416^{* * *}$ & $.413^{* * *}$ \\
Conscientiousness * interest & & & -.032 \\
Environmental concern & & $.536^{* * *}$ & $.535^{* * *}$ \\
Conscientiousness ${ }^{*}$ environmental & & & $-.112^{* *}$ \\
concern & $.457^{* * *}$ & $.613^{* * *}$ & $.610^{* * *}$ \\
\hline Girl & & & \\
Education (ref. professional education) & $1.074^{* * *}$ & $.706^{* * *}$ & $.702^{* * *}$ \\
General education & $.544^{* * *}$ & $.343^{* *}$ & $.342^{* *}$ \\
Technical education & $.675^{* *}$ & $.525^{*}$ & $.536^{*}$ \\
Arts education & .080 & .174 & .177 \\
\hline Nagelkerke R ${ }^{2}$ & 3109 & 3074 & 3074 \\
\hline $\mathrm{N}$ & & 309 &
\end{tabular}

Source: PCSS 2012. Ordered logistic regression. Entries are coefficients (standard errors) and significances. Sign: $\mathrm{p} \leq 0.05: * ; \mathrm{p} \leq 0.01:^{* *} ; \mathrm{p} \leq 0.001$ : $^{* *}$. 
